\title{
Challenges of Correcting Spelling Errors among Standard Seven Learners in Nandi South Sub-County, Kenya
}

\author{
Joel Josumei Mbugua $^{1 *}$, Benard Angatia Mudogo ${ }^{2}$, Teresa A. Okoth-Oluoch ${ }^{2}$ \\ ${ }^{I}$ Postgraguate Student, Masinde Muliro University of Science and Technology, Kenya \\ ${ }^{2}$ Lecturers, Masinde Muliro University of Science and Technology, Kenya
}

*Corresponding Author: Joel Josumei Mbugua, Postgraguate Student, Masinde Muliro University of Science and Technology, Kenya

\begin{abstract}
Attainment of standardized spelling in English is a very important aspect towards achievement of skills in writing. However, existing data from the Ministry of Education in Kenya has shown that there is a clear indication among learners that points to a situation of struggling with spelling skills in writing. It was against this background that this paper was set out to assess the role of instructions on spelling errors in English tests among learners of a Second Language. The researcher wanted to establish the challenges that teachers face in correcting learners spelling errors in English tests. Data for the paper came from analysis of compositions and other tests written by learners from selected Kenyan primary schools in Nandi Sub County. It is hoped that the findings of this paper will benefit teachers of English by proposing relevant methods of spelling instructions that might improve spelling performance among learners of Nilotic background This investigation is also adds knowledge in spelling instruction strategies particularly among bilingual learners of English as a Second Language in written tests.
\end{abstract}

Keywords: spelling, errors, instruction, orthography, insertion, deletion.

\section{INTRODUCTION}

Many educational institutions across the globe consist of large population of linguistically diverse students learning the basic skills of writing and reading in English as a second language (ESL). Second language acquisition (SLA) therefore remains a fundamental field in promoting Second Language (L2) literacy among different groups of non-native speakers of English. Since English acquired special status in at least 75 countries in the world with over two billion speakers (Bear et at 2000), there is a growing demand for language literacy skills in English. In this regard, strategies for spelling instruction should be given prominence in the teaching of English as an L2.

As a matter of importance, however, many learners in many countries teaching English as a second language(L2) continue to experience difficulty in acquiring even the most Basic English literacy skills and therefore face the risk of reading difficulties and school drop-out (Gottardo, 2002). Literacy is therefore important in our society today, and it cannot be wished away since learning to read and write is the foundation of academic excellence (Allaith \& Joshin, 2011 \& Lyon, 2011). Failure of one to acquire proper literacy skills, including spelling can have disastrous consequences such as loss of job opportunities, failure to get school admission, poor grades and score on standardized tests among other issues. Therefore, there was need for an investigation on the role of instructions on spelling errors in learners' written tests.

According to Graddol (1997) reports on the population of English speakers has increased tremendously, and a majority of these English learners demonstrate low proficiency levels in English language literacy. If these kinds of learners want to be successful in second language acquisition (SLA), basic literacy skills such as reading and writing need to become important. One of the areas where such learners have had challenges is in the spelling performance. If learners lack sufficient word knowledge, it inhibits their reading and comprehension of texts which leads to poor performance. Learners can experience frustration and dissatisfaction whenever they find themselves under-performing in writing skills. 
Similarly, Cook (1997) observes that spelling features prominently in the national curriculum in countries such as UK and Australia. Examination boards are instructed to deduct marks for poor spelling in all the subjects. In Kenya for instance, learners are heavily penalized for any type of spelling errors made in National examinations inthe writing of English compositions and essays. Spelling is so much an important aspect in Second Language Learning (SLL) because of its role in writing and reading. In the United States, for example, some of the L1 children and adults still struggle with the basic literacy skills adults still struggle with the basic literacy skills such as reading and writing (National Institute of Child health and Human Development, 2000). Literacy skills instructions therefore, are an essential component of success in any society where so much information is conveyed by the written word Rayner et. al. (2001). It is against this background that this study sought to find out teachers' strategies of spelling instructions among Standard Seven learners in Kenya public primary schools.

Most L2 research studies have tried to find ways to identify factors either promoting or impeding effective performance of L2. One theory that discusses the relationship between L1 and L2 in reference to literacy acquisition is that of Metacognition Theory (Flavell, 1979). The theory suggests that teachers should help learners to understand the way they learn; in other words, it is designed to help learners to reflect on the way they learn. This eventually assists them know their mistakes in spelling and correct them. Metacognition strategy helps learners build their capacity of self-correction in writing skills. In this regard, the researcher sought to establish the relationship between spelling instruction and performance within the framework of the Metacognition Theory. The teachers' roles within the tenets of this theory were evaluated.

\section{LITERATURE REVIEW}

Teaching of spelling among bilingual learners presents teachers with very many challenges in the process of teaching. Some of these challenges are;

\subsection{Role of Phonological Knowledge in Spelling}

Phonological knowledge among learners in spelling is lacking. Abu-Rabia (2000) and Kernigham (1995) argued that, because learners lack phonological knowledge in English pronunciation, effects of phonological processes, affects spelling of learners whose L1 is not English. This was because phonological abilities enable one to manipulate and distinguish sounds within spoken words, (Castels \& Coltheart, 2004). This paper supports the hypothesis that phonological processing skills in L1 would transfer to English and many times would lead to spelling errors in written tests.

\subsection{Cross-Language Transfer}

Although skills in L1 processes have been discovered to assist learners transcend to L2, most learners would often transfer those skills to L2. Whether those skills are appropriate or not to the L2 form system, learners would assume the processing is the same in both languages in terms of their phonology, pragmatics, Metalinguistic awareness and production, hence causing spelling errors in written tests, (Kholood and Schmitt, 2012).

\subsection{Negative Attitude towards Spelling}

Learners' attitude towards spelling is a key motivational component in spelling. Parker, (1991) argues that Second Language learning is influenced by learners' attitude towards the language. Positive attitude makes learners want to learn the skillsof processing a given language than those with negative attitude. Rankin, Bruning \& Timme, (1994) argued that attitude and perception on spelling and writing as well as their beliefs about themselves as spellers relate strongly to their actual spelling and writing performance.

\subsection{Dyslexia}

As a language learning difficult, Dyslexia makes learning of sounds difficult because dyslexic learners cannot isolate sounds from words, match those sounds to letters and blend sounds into words. International Dyslexic Association argues that dyslexic learners struggle with spelling and face serious obstacles in learning. This explains why some learners present spelling errors yet they can recognize words well when given to read, (Denkla, 1976). 


\subsection{Visual Processing Issues on Spelling}

According to Allah, (1997) some learners struggle with spelling due to brain-based issues that makes it harder to perceive or make sense. This also makes it harder to memorize spelling patterns and some may face trouble in reading cursive or less common fonts which can make it even harder to remember spelling of words e.g. letters such as 'p' and ' $q$ '.

\subsection{Short Term Memory}

Baker, (2001) argues that poor spellers often have trouble in remembering and recalling the features of a language that certain letters represents. Such learners have weaknesses in remembering the individual phoneme in words and the meaningful parts (morphemes) of longer words such as subjectable.

\subsection{Sound System Differences between $\mathrm{L} 1$ and $\mathrm{L} 2$}

Moosa, (1972) argues that the differences in the sound systems of English and other L1 languages lead to errors of spelling in written tests. Other linguists such as Frith (1979, p.386) and Ehri (1987) have also noted that English orthography is partially guided by the straightforward sound-letter correspondence and most learners are not aware of this hence the errors of spelling.

\subsection{English as a Second Language}

Graham (1983) argues that English as a Second Language (ESL), is complex because nearly fifty percent $(50 \%)$ of English words are predictable and are based on sound-letter correspondence alone, (e.g. slap, pitch, boy). In addition, thirty-seven percent (37\%) of more common words are almost predictable except for one sound (, e.g. knit and boat). In his research he argues that other information such as the language from which the word came from (e.g. Old English, Latin, Greek, or French) and word meaning also helps learners know the spelling of a particular word.

\subsection{Spelling Reversals and Sequencing of Letters}

Spelling reversals of easily confused letters such as $/ \mathrm{b} /$ as $/ \mathrm{p} / \mathrm{/} / \mathrm{s} /$ as $/ \mathrm{z} /$ or sequencing of letters such as 'wnet' for 'went' are sometimes a manifestation of underlying language weaknesses rather than of visually-based problem, (O’Conor,2003)

\section{MeThodology}

This investigation targeted 145 public primary schools in Nandi South Sub-County which were purposively sampled and stratified into categories of Boys boarding, Girls boarding, Mixed boarding and mixed day. A total of thirty-six (36) schools representing $25 \%$ of the schools sampled, were randomly selected. Stratified random sampling was used to select 122 learners out of 2240 learners. Thirty-six (36) teachers of English, each representing a school were also used in the study. This gave a total of one hundred and fifty-eight (158) respondents. The study employed a descriptive design approach in presenting and analyzing data. Three English compositions and cloze tests were given and were analyzed to identify the spelling errors made. These errors were then described and categorized according to three phonological processes of omission/deletion, insertion and phoneme substitution.

\section{RESULTS AND DISCUSSION}

The data analysis revealed that phonological influences from Nandi speakers from whom the majority of learners came from, was majorly the cause of spelling errors because learners write what they say. This is based on the fact that languages differ in both their phonological and morphemic structure. When Nilotes, and in particular Nandi speakers learn a new language, there is a tendency among them of importing their first language patterns erroneously. The spelling errors made, have been found to follow three phonological processes: omission/deletion, insertion and phoneme substitution.

\subsection{Omission/Deletion}

This is the removal of phonological segments from a word or words. From the sampled compositions, learners failed to provide the correct spellings for words with silent consonants and vowels. Learners did not write silent consonants or silent vowels for those silent graphemes because the letters were not 
Challenges of Correcting Spelling Errors among Standard Seven Learners in Nandi South Sub-County, Kenya

sounded in speech. What was written is what was sounded during pronunciation leading to the deviant forms of omission/deletion of silent consonants and silent vowels. Some of the words that had omission are analyzed below;

Correct word wrong form

Often

ofen

Nee

knee

Government

govement/govenment/goverment

Surprise

suprise

Handkerchief

hankerchief

Honest

onest

Silent graphemes in the examples above presented segmental errors in words that were not articulated in speech were common in learners' written tests. All these examples were classified as silent consonants and silent vowels. In the above examples learners had difficulties in words whose three consonants followed one another successively like in 'government', and 'handkerchief' especially if consonants come in the middle of a word.

Table1: Distribution of spelling challenges caused as a result of silent graphemes

\begin{tabular}{|c|c|c|c|c|c|c|c|c|c|c|c|c|c|}
\hline \multirow{2}{*}{\begin{tabular}{|l|}
$\begin{array}{l}\text { School } \\
\text { category }\end{array}$ \\
\end{tabular}} & \multirow[t]{2}{*}{ N.L } & \multicolumn{2}{|c|}{$\begin{array}{l}\text { *ofen } \\
\text { often }\end{array}$} & \multirow{2}{*}{$\begin{array}{l}* \text { nee } \\
\text { knee } \\
\text { WSPCSP }\end{array}$} & \multirow{2}{*}{\multicolumn{4}{|c|}{\begin{tabular}{|l|l|l} 
*govement for & *suprise \\
government & surprise \\
WSP $\quad$ CSP & WSP CSP \\
\end{tabular}}} & \multicolumn{2}{|c|}{$\begin{array}{l}\text { *hankerchief } \\
\text { Handkerchief }\end{array}$} & \multirow{2}{*}{\multicolumn{2}{|c|}{$\begin{array}{l}* \text { onest } \\
\text { Honest } \\
\text { WSP CSP } \\
\end{array}$}} & \multirow[t]{2}{*}{$\begin{array}{l}\text { CSP } \\
\%\end{array}$} \\
\hline & & & CSP & & & & & & WSP & CSP & & & \\
\hline Girls boarding & 10 & 0 & 10 & 9 & 1 & 9 & 1 & 9 & 2 & 8 & 0 & 10 & $92 \%$ \\
\hline Boys boarding & 10 & 1 & 9 & 2 & 2 & 8 & 3 & 7 & 0 & 10 & 0 & 10 & $90 \%$ \\
\hline $\begin{array}{l}\text { Mixed } \\
\text { boarding }\end{array}$ & 10 & 2 & 8 & 10 & 3 & 7 & 3 & 7 & 0 & 10 & 0 & 10 & $87 \%$ \\
\hline Mixed day & 10 & 2 & 8 & 9 & 4 & 6 & 5 & 5 & 4 & 6 & 3 & 7 & $68 \%$ \\
\hline Total & 40 & 5 & 35 & 38 & 1030 & & 12 & 28 & 6 & 34 & 3 & 37 & \\
\hline
\end{tabular}

Note: NL: Number of learners, WSP =Wrong spelling, CSP-Correct spelling,

Source: Field Data

In the pronunciation of the word often /ofn/ tesound /t/ is silent. Therefore, the learner whose mother tongue is Nandi transferred to orthography heard in the pronunciation of the word. Nandi phonology has no silent sounds. As a result, Nandi students tend to omit the sounds that are not articulated in the Target Language (TL). This spelling error is caused by the spelling system of English. Communication strategies which have potentially conscious plans for solving what an individual present as a problem in reaching a particular communicative goal. Tarone (1983) argues that Second Language learners employ distinct communication strategies in order to compensate for their limited knowledge of the target language. This strategy involves topic avoidance and/or message abandonment as a result of inadequate mastery of the target language.

\subsection{Challenges Caused Due to Consonant Substitution}

The consonants that are not found in Nandi are substituted with those sounds found in the language. Most consonants in English are not found in Nandi; therefore, sounds are substituted with those found in the language leading to errors of spelling. This is illustrated in the examples given below.

Table2: Distribution of challenges caused by consonants substitution

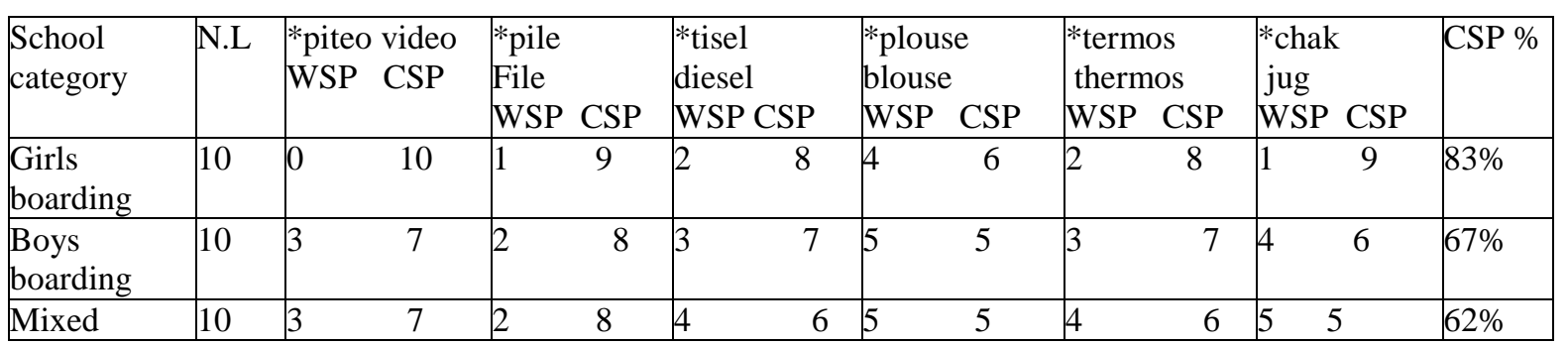


Challenges of Correcting Spelling Errors among Standard Seven Learners in Nandi South Sub-County, Kenya

\begin{tabular}{|c|c|c|c|c|c|c|c|c|c|c|c|c|c|c|}
\hline boarding & & & & & & & & & & & & & & \\
\hline Mixed day & 10 & 5 & 5 & 4 & 6 & 5 & 5 & 6 & 4 & 6 & 4 & 6 & 4 & $47 \%$ \\
\hline Total & 40 & 11 & 29 & 9 & 31 & 14 & 26 & 20 & 20 & 15 & 25 & 16 & 24 & \\
\hline
\end{tabular}

Source: Field data

Note: NL: Number of learners, WSP =Wrong spelling, CSP-Correct spelling,

Video/vidəu/

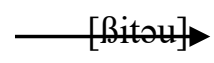

File/fail/

[Bail]

Labio-dental fricatives, /f/ and /v/ are substituted with the voiced bilabial fricative $/ 囚 /$ as shown above.

Diesel / dizl/ [tisl]

Blouse /blauz/

[Blaus]

The voiced alveolar fricative /z/ is also substituted by its voiceless counterpart /s/, as seen in the example above.

The voiced alveolar plosive /d/ as well as the voiceless dental fricative $/ \square$ /are substituted by the voiceless alveolar plosives / $\mathrm{t} /$ as seen in the examples below:

Theatre/ $\square$ iətə $\quad[$ tiətə]

Thermos / $\square$ 3:məs/

[t3:mas]

The voiced palato-alveolar affricate $/ d /$ and the voiced palato- alveolar fricative $/ 3 /$ are also substituted by the voiceless palato-alveolar affricative $/ \mathrm{t} /$ as shown in the examples:

Below

Jug $/ \mathrm{d} / \mathrm{g} /$

Garage/gæra3/

$\stackrel{[\mathrm{gak}] \longrightarrow}{\longrightarrow}$

$\stackrel{[\mathrm{Værat5]}}{\longrightarrow}$

From the examples above, it is clear that learners from the Nandi community just like any other learners from other natural languages uses substitution as a strategy for adopting non-native sounds in the language.

These errors of spelling also occurred due to the language transfer which is the occurrence of fossilized linguistic items and rules in the language of a second language learner as a result of first language Selinker (1972). Language transfer plays a role in the acquisition of grammatical aspects. Some of the rules in inter-language system may be as a result of transfer from the learner's first language. Learners use their L1 to create their own language system. The errors in the use of L2 result mainly from L1.The difference between L1 and L2 is the reason for the occurrence of spelling errors. The learnt version is the erroneous version. Some elements of L1 are transferred to L2. Since the sounds do not exist in their language.

\subsection{Challenges Due to Double Consonant Graphemes}

In this category, some learners gave wrong forms of spellings because they failed to double consonants in some words as expected in the English writing convention. Examples of words that were misspelt are tabulated below:

Table3: Distribution of challenges due to double consonants

\begin{tabular}{|l|l|ll|ll|l|l|l|l|l|}
\hline $\begin{array}{l}\text { School } \\
\text { category }\end{array}$ & $\begin{array}{l}\text { No } \\
\text { LN }\end{array}$ & \multicolumn{2}{|l|}{$\begin{array}{l}\text { Committee } \\
\text { WSP }\end{array}$} & \multicolumn{2}{l|}{$\begin{array}{l}\text { Puzzle } \\
\text { WSP }\end{array}$} & CSP & \multicolumn{2}{l|}{$\begin{array}{l}\text { Parallel } \\
\text { WSP CSP }\end{array}$} & $\begin{array}{l}\text { Bonnet } \\
\text { WSP CSP }\end{array}$ & CSP \% \\
\hline $\begin{array}{l}\text { Girls } \\
\text { boarding }\end{array}$ & 10 & 2 & 8 & 4 & 6 & 4 & 6 & 3 & 7 & $67.5 \%$ \\
\hline $\begin{array}{l}\text { Boys } \\
\text { boarding }\end{array}$ & 10 & 4 & 6 & 5 & 5 & 6 & 4 & 55 & & $50 \%$ \\
\hline $\begin{array}{l}\text { Mixed } \\
\text { boarding }\end{array}$ & 10 & 5 & 5 & 5 & 5 & 6 & 4 & 5 & 5 & $47.5 \%$ \\
\hline Mixed day & 10 & 7 & 3 & 6 & 4 & 7 & 3 & 6 & 4 & $35 \%$ \\
\hline Total & 10 & 18 & 22 & 16 & 24 & 10 & 30 & 16 & 24 & \\
\hline
\end{tabular}


Challenges of Correcting Spelling Errors among Standard Seven Learners in Nandi South Sub-County, Kenya

Source: Field data

Note: NL: Number of learners, WSP =Wrong spelling, CSP-Correct spelling,

In the examples above, learners' misspelt words such as 'committee', 'puzzle', 'parallel, and 'bonnet'due to their failure to double the consonant to conform to the writing conventions of English. All these words consist of double consonants which learners misspelt. In his research on generative phonology, Maiyo (2007) argues that Nandi orthography does not have double consonants while in English consonants are doubled, for example, the English word "committee" which is pronounced as /kpmiti: /.

\subsection{Challenges Due to the Discrepancy between the English Sound System and the Spelling System}

Errors in spelling were detected where learners' misspelt words due to the discrepancy between the English phonology and the orthography. Examples of misspelt words due to this nature are shown in the Table 4.7 below:

Table4: Frequency of spelling challenges due to the discrepancy between the English sound system and the spelling system

\begin{tabular}{|c|c|c|c|c|c|c|c|c|c|c|c|c|}
\hline $\begin{array}{l}\text { School } \\
\text { category }\end{array}$ & N.L & $\begin{array}{l}{ }_{*}^{*} \text { couf } \\
\text { WSP }\end{array}$ & $\begin{array}{l}\text { cough } \\
\text { CSP }\end{array}$ & $\begin{array}{l}\text { *sand } \\
\text { WSP }\end{array}$ & $\begin{array}{l}\text { unday } \\
\text { CSP }\end{array}$ & $\begin{array}{l}\text { *ricive } \\
\text { WSP }\end{array}$ & $\begin{array}{l}\text { receive } \\
\text { CSP }\end{array}$ & $\begin{array}{l}* \text { coll } \\
\text { WSP }\end{array}$ & $\begin{array}{l}\text { call } \\
\text { CSP }\end{array}$ & $\begin{array}{l}{ }_{*}^{*} \text { weil } \\
\text { WSP }\end{array}$ & $\begin{array}{l}\text { wail } \\
\text { CSP }\end{array}$ & $\begin{array}{l}\% \\
\text { CSP }\end{array}$ \\
\hline $\begin{array}{l}\text { Girls } \\
\text { boarding }\end{array}$ & 10 & 1 & 9 & 0 & 10 & 1 & 9 & 0 & 10 & 1 & 9 & $94 \% \%$ \\
\hline $\begin{array}{l}\text { Boys } \\
\text { boarding }\end{array}$ & 10 & 3 & 7 & 0 & 10 & 3 & 7 & 2 & 8 & 3 & 7 & $78 \%$ \\
\hline $\begin{array}{l}\text { Mixed } \\
\text { boarding }\end{array}$ & 10 & 4 & 6 & 2 & 8 & 3 & 7 & 2 & 8 & 4 & 6 & $70 \%$ \\
\hline $\begin{array}{l}\text { Mixed } \\
\text { day }\end{array}$ & 10 & 6 & 4 & 4 & 6 & 5 & 5 & 6 & 4 & 6 & 4 & $46 \%$ \\
\hline Total & 40 & 14 & 26 & 6 & 34 & 12 & 28 & 10 & 30 & 14 & 26 & \\
\hline
\end{tabular}

Note: NL: Number of learners, WSP =Wrong spelling, CSP-correct spelling,

Source: Field Data

Learners misspelt the word "cough" and spelt it as 'couf' .In the above misspelt word, the letter ' $\mathrm{f}$ ' takes the place of letters 'gh' in English. The learners relied on their first language knowledge where they used sound $/[\mathrm{f} /]$ to match the pronunciation they hear from English word $/ \mathrm{kpf} /$ since the word in target language is pronounced as $/ \mathrm{kpf} /$.

The word Sunday is pronounced as /s $\Lambda$ ndei/ in English. The equivalent of sound $/ \Lambda /$ in Nandi is sound /a/ which sepresented by letter 'a". Therefore, in writing, the learner applied the phonology of Nandi and its orthography leading to the deviant form above.

The word receive is pronounced as/iisi:v/ in English. In this case, the sound /i/ takes care of the letters 'ie' in English pronunciation. In Nandi, sound /i/ is equivalent to letter ' $\mathrm{I}$ ', so there is /I/ in English pronunciation. Learners misspelt the word 'call 'and instead spelt it as 'coll'. In English, the word is pronounced as $/ \mathrm{ko:} / 1 /$. In the misspelt word, letter 'o' replaces letter ' $\mathrm{a}$ '.

\subsection{Challenges Created due to Retention of Letter ' $e$ ' before a suffix}

When a suffix is added to some of the English words that end with the vowel 'e', the vowel 'e' 'is omitted. The 'e'is silent in speech and when it fails to be dropped in writing, a misspelling occurs. Spelling errors were seen where learners failed to delete letter 'e 'before adding a suffix as shown in the table below:

Table5: Distribution of challenges due to retention of letters ' $e$ '

\begin{tabular}{|c|c|c|c|c|c|c|c|}
\hline $\begin{array}{l}\text { School } \\
\text { category }\end{array}$ & N.L & $\begin{array}{l}\text { *receveing } \\
\text { receiving } \\
\text { WSP CSP }\end{array}$ & $\begin{array}{l}\text { *deleteing } \\
\text { deleting } \\
\text { WSP CSP }\end{array}$ & $\begin{array}{l}\text { *observeable } \\
\text { observable } \\
\text { WSP CSP }\end{array}$ & $\begin{array}{l}\text { *urgueing } \\
\text { arguing } \\
\text { WSP CSP }\end{array}$ & $\begin{array}{l}\text { *categerizeing } \\
\text { categorizing } \\
\text { WSP CSP }\end{array}$ & $\begin{array}{l}\% \\
\text { CSP }\end{array}$ \\
\hline $\begin{array}{l}\text { Girls } \\
\text { boarding }\end{array}$ & 10 & 1 & 10 & 9 & 28 & 1 & \\
\hline
\end{tabular}


Challenges of Correcting Spelling Errors among Standard Seven Learners in Nandi South Sub-County, Kenya

\begin{tabular}{|l|l|ll|ll|lll|l|l|l|}
\hline $\begin{array}{l}\text { Boys } \\
\text { boarding }\end{array}$ & 10 & 3 & 7 & 19 & & 4 & 6 & 37 & 28 & \\
\hline $\begin{array}{l}\text { Mixed } \\
\text { boarding }\end{array}$ & 10 & 4 & 6 & 2 & 8 & 3 & 7 & 46 & 4 & 6 \\
\hline $\begin{array}{l}\text { Mixed } \\
\text { day }\end{array}$ & 10 & 55 & & 37 & & 4 & 6 & & 55 & 46 & \\
\hline Total & 40 & 13 & 26 & 6 & 34 & 12 & 28 & 1426 & 11 & 29 & \\
\hline
\end{tabular}

Note: NL: Number of learners, WSP =Wrong spelling, CSP-Correct spelling.

Source: Field Data

In the above examples, spelling errors can be said to be caused by the influence of the first language phonology since some Nandi vowel sounds are not deleted and there are no silent sounds among speakers of Nandi.

\subsection{Challenges Due to Homophones}

This was another source of errors in the learners' work. Learners failed to provide the correct spellings for the homophones due to their reliance on what they heard. They gave alternative words which are pronounced like the intended forms.

Table6: Distribution of challenges due to Homophones

\begin{tabular}{|c|c|c|c|c|c|c|c|c|c|c|}
\hline $\begin{array}{l}\text { School } \\
\text { category }\end{array}$ & N.L & $\begin{array}{l}\text { *Flov } \\
\text { WSP }\end{array}$ & $\begin{array}{l}\text { lower } \\
\text { CSP }\end{array}$ & $\begin{array}{l}\text { *Mail } \\
\text { WSP }\end{array}$ & $\begin{array}{l}\text { Male } \\
\text { CSP }\end{array}$ & $\begin{array}{l}* \text { Our } \\
\text { WSP }\end{array}$ & $\begin{array}{l}\text { Hour } \\
\text { CSP }\end{array}$ & $\begin{array}{l}{ }^{*} \text { see } \\
\text { WSP }\end{array}$ & $\begin{array}{l}\text { sea } \\
\text { CSP }\end{array}$ & $\begin{array}{l}\% \\
\text { CSP }\end{array}$ \\
\hline $\begin{array}{l}\text { Girls } \\
\text { boarding }\end{array}$ & 10 & 2 & 8 & 2 & 8 & 1 & 9 & 2 & 8 & $32(80 \%)$ \\
\hline $\begin{array}{l}\text { Boys } \\
\text { boarding }\end{array}$ & 10 & 4 & 6 & 3 & 7 & 2 & 8 & 4 & 6 & $27(68 \%)$ \\
\hline $\begin{array}{l}\text { Mixed } \\
\text { boarding }\end{array}$ & 10 & 5 & 5 & 4 & 6 & 5 & 5 & 6 & 3 & $19(46 \%)$ \\
\hline Mixed day & 10 & 7 & 3 & 6 & 4 & 6 & 4 & 7 & 3 & $14(35 \%)$ \\
\hline Total & 40 & 13 & 22 & 15 & 25 & 12 & 26 & 19 & 20 & \\
\hline
\end{tabular}

Note: NL: Number of learners, WSP =Wrong spelling, CSP-Correct spelling.

Source: Field Data

Video /vidəu/

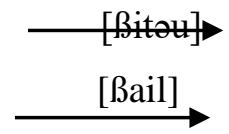

File/fail/

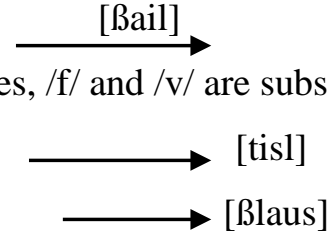

Labio-dental fricatives, /f/ and /v/ are substituted with the voiced bilabial fricative / / / as shown above.

Diesel /dizl/

Blouse / blauz

$$
\text { [Blaus] }
$$

The voiced alveolar fricative /[z]/ is also substituted by its voiceless counterpart /s/, as seen in the example above. The voiced alveolar plosive /d/ as well as the voiceless dental fricative / $\square$ /are substituted by the voiceless alveolar plosives /t/ as seen in the examples below:

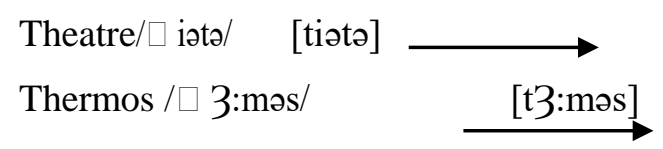

The voiced palato-alveolar affricate $/ \mathrm{d} /$ and the voiced palato- alveolar fricative $/ 3 /$ are also substituted by the voiceless palato-alveolar affricative $/ \mathrm{t} /$ as shown in the examples

Below

$\operatorname{Jug} / \mathrm{d} \Lambda \mathrm{g} /[\mathrm{tgak}]$

Garage/gæra3/

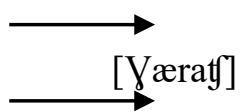

From the examples above, it is clear that Nandi like any other natural language uses substitution as a strategy for adopting non-native sounds in the language by utilizing those sounds found in the language. 
Challenges of Correcting Spelling Errors among Standard Seven Learners in Nandi South Sub-County, Kenya

\subsection{Challenges of Spelling Created by Vowel Length}

Maiyo (2007) argues that errors may arise if a Nandi learner is unable to distinguish between short and long vowels. Some learners" were unable to distinguish between these vowels which led to errors as shown in Table 4.10 below:

Table7: Distribution of challenges created by vowel length

\begin{tabular}{|l|l|ll|lc|lc|ll|l|}
\hline $\begin{array}{l}\text { School } \\
\text { category }\end{array}$ & N.L & $\begin{array}{l}* \text { To } \\
\text { WSP }\end{array}$ & $\begin{array}{l}\text { Too } \\
\text { CSP }\end{array}$ & $\begin{array}{l}* \text { Sit } \\
\text { WSP }\end{array}$ & $\begin{array}{r}\text { seat } \\
\text { CSP }\end{array}$ & $\begin{array}{l}* \text { Sin } \\
\text { WSP }\end{array}$ & $\begin{array}{l}\text { sean } \\
\text { CSP }\end{array}$ & $\begin{array}{l}\text { *Slip sleep } \\
\text { WSP }\end{array}$ CSP & $\begin{array}{l}\% \\
\text { CSP }\end{array}$ \\
\hline $\begin{array}{l}\text { Girls } \\
\text { boarding }\end{array}$ & 10 & 0 & 10 & 1 & 9 & 2 & 8 & 3 & 7 & $85 \%$ \\
\hline $\begin{array}{l}\text { Boys } \\
\text { boarding }\end{array}$ & 10 & 2 & 8 & 3 & 7 & 4 & 6 & 4 & 6 & $66 \%$ \\
\hline $\begin{array}{l}\text { Mixed } \\
\text { boarding }\end{array}$ & 10 & 3 & 7 & 4 & 6 & 5 & 5 & 6 & 4 & $55 \%$ \\
\hline Mixed day & 10 & 5 & 5 & 5 & 5 & 6 & 4 & 7 & 3 & $43 \%$ \\
\hline Total & 40 & 10 & 30 & 13 & 27 & 17 & 23 & 12 & 20 & \\
\hline
\end{tabular}

Note: NL: Number of learners, WSP =Wrong spelling, CSP-Correct spelling.

Source: Field Data

The example above, learners misspelt the word 'too 'and 'to' In English, the word 'too' is pronounced as /tu: / and it is a long vowel while the misspelt one, * 'to' is pronounced as /tu/ which is a short vowel.

\subsection{Challenges of Spelling Created Due to Absence of the Sound in Nandi}

The English sound system and that of Nandi differ. Some sounds that are in English do not exist in Nandi (Maiyo, 2007). For example, sounds like /v, g, z, d/. As a result of this, in the tests given, spelling errors were exhibited by the Nandi learners whose first language is Nandi.

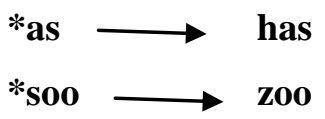

Table8: Distribution of Challenges of spelling created Due to Absence of the Sound in Nandi

\begin{tabular}{|c|c|c|c|c|c|c|c|c|c|c|c|}
\hline $\begin{array}{l}\text { School } \\
\text { category }\end{array}$ & N.L & $\begin{array}{l}\text { *as } \\
\text { WSP }\end{array}$ & $\begin{array}{l}\text { has } \\
\text { CSP }\end{array}$ & $\begin{array}{l}\text { *soo } \\
\text { WSP }\end{array}$ & $\begin{array}{r}\text { zoo } \\
\text { CSP }\end{array}$ & $\begin{array}{l}\text { *Hey } \\
\text { WSP }\end{array}$ & $\begin{array}{l}\text { they } \\
\text { CSP }\end{array}$ & $\begin{array}{l}\text { *lepylevy } \\
\text { WSP CSP }\end{array}$ & $\begin{array}{rr}\text { *traw } & \text { draw } \\
\text { WSP } & \text { CSP } \\
\end{array}$ & $\begin{array}{l}\% \\
\text { CSP }\end{array}$ & WSP \\
\hline $\begin{array}{l}\text { Girls } \\
\text { boarding }\end{array}$ & 10 & 0 & 10 & 1 & 9 & 1 & 9 & 8 & 37 & $86 \%$ & $14 \%$ \\
\hline $\begin{array}{l}\text { Boys } \\
\text { boarding }\end{array}$ & 10 & 2 & 8 & 1 & 9 & 4 & 6 & 4 & 55 & $68 \%$ & $32 \%$ \\
\hline $\begin{array}{l}\text { Mixed } \\
\text { boarding }\end{array}$ & 10 & 4 & 6 & 3 & 7 & 4 & 6 & 5 & 64 & $56 \%$ & $44 \%$ \\
\hline Mixed day & 10 & 5 & 5 & 6 & 4 & 6 & 4 & 4 & 73 & $40 \%$ & $60 \%$ \\
\hline Total & & & & & & & & & & & \\
\hline
\end{tabular}

Note: NL: Number of learners, WSP =Wrong spelling, CSP-Correct spelling.

Source: Field Data

English sounds that are not found in the L2 learners spoken language was seen as the cause of errors of spelling. Repeated practice in spelling instruction provided by teachers went a long way in improving spelling instruction and performance.

According to researches such as (Cook, 1997; Ehri, 1987; Ingebrand, 2013; Peters, 1985; Spencer, 2000 and Tavosanis, 2007), the authors argue that English is not totally phonetic; that is, "English orthography is only partially guided by straightforward sound-letter correspondence" (Frith, 1979, p.386). Therefore, relying on sound-letter rules for spelling English words would be problematic. From the Table 4.11 above, example, the word 'has' was misspelt by some learners. They spelt it as * 'as'. The correct pronunciation in English is /hæz/. The learners omit the consonant sound $/ \mathrm{h} /$. This error can be attributed to the influence of Nandi phonology as the glottal sound $/ \mathrm{h} /$ is not available in the phonemic inventory of the Nandi language. 
In example six learners misspelt the word 'zoo'. In English pronunciation, the word 'Zoo' is pronounced as /zu: /. The voiced alveolar fricative sound /z/ is not present inNandi sound system. The learners therefore, replace it with its voiceless counterpart sound

/s/. The Nandi phonology therefore can be said to be responsible for the misspelling of this word. In the example above, learners misspelt the word 'they "and instead spelt it as *'tey'. Dental fricatives do not exist in Nandi. The voiceless dental fricative / $ð$ therefore does not exist. The closest sound to the voiceless dental fricative / // in Nandi is the voiceless alveolar fricative /t/.

The learners used the alveolar fricative /t/ in place of the dental fricative/ð/ in English.

\section{CONCLUSION}

Learners should be encouraged to write words with problematic sounds and commonly misspelt words as well as words with longer structures. This practice helps the learners to master the different strings of letters that are often found together. In addition, they were able to identify sounds in isolation and when they occur in different words. The teachers could reinforce this by giving oral lessons, dictation exercises and oral quizzes or tests regularly.

Teachers should go through the work with the learners. The teacher should stress on the identification of the errors. And encourage learners identify the errors with their guidance. The teacher should focus on helping learners become more independent. During this exercise, an explanation should be given as to why a word is wrong. This helps the learners to understand the errors so that they should not repeat them in future. As the words are corrected, the correct forms should be written.

\section{REFERENCES}

[1] Abu-Rabia, S. (2000). Effects of exposure to literary Arabic on reading comprehension in a diglossic situation. Reading and writing, 13(1-2), 147-157.

[2] Allah L. (1997). Learning to spell in the classroom. In CA Perfetti L. Rieben \& M. Fayol (Eds.), Learning to spell. London, UK: Lawrence Erlbeam Associates.

[3] Allaith, Z. A., \& Joshi, R. M. (2011). Spelling performance of English consonants among students whose first language is Arabic. Reading and Writing, 24(9), 1089-1110.

[4] Baker, M. (2001). The Atoms of Language; The Minds Hidden Rules of Grammar Basic Books.

[5] Cook, V (2004) The English writing system: Hodder Arnold.

[6] Cook, G. (2000). Language play, language learning. Oxford University Press.

[7] Denckla, M, B., \& Rudel, R. G. (1976). Naming of object drawings by dyslexic and other learningdisabled children. Brain and Language, 3, 1-6

[8] Ehri, L.C. (1997). Learning to Read and Learning to Spell Are one and the same. Almost. In C.A.

[9] Ehri, L.C. \& Wilce, L.S. (1987). Does learning to spell help beginners learn to read.

[10] Flavell J.H (1979). Metacognition and Cognitive Monitoring. A new Era of Cognitive Developmental Inquiry. American Psychology.

[11] Frith, V. (1983). The similarities and differences in reading and spelling problems. In Rutter (Ed.), Developmental neuropsychiatry (pp. 453-475). New York: Guilford Press.

[12] Frith, U. (1979). Reading by eye and writing by ear. In Processing of visible language (pp. 379-390). Springer, Boston, MA.

[13] Flavell, J. H., \& Wellman, H. M. (1975). Metamemory.

[14] Gottardo, A. (2002). The relationship between language and reading skills in bilingual Spanish-English speakers. Topics in language disorders, 22(5), 46-70.

[15] Graham S. (1983). Effective Spelling Instruction. Elementary School Journal. Den Bosch. Netherlands: Malmberg.

[16] Graham, S., \& Richards, T., Berninger, V. W., Abbott, R. D., Abbott, S. P., (2002). Writing and reading: Connections between language by hand and language by eye. Journal of learning disabilities, 35(1), 3956.

[17] Ingebrand, S. (2013). Spelling as it relates to literacy: Reading, writing, and language (Doctoral dissertation, The Florida State University).

[18] Kernighan, B. W. (2007). A regular expression matcher. Oram and Wilson [OW07], 1-8.S

[19] Maiyo, E.J. (2007). Nandi phonology: Natural Generative Phonology approach. M.A Dissertation, UON. 
[20] National Reading Panel (US), National Institute of Child Health, \& Human Development (US). (2000). Report of the National Reading Panel: Teaching children to read: An evidence-based assessment of the scientific research literature on reading and its implications for reading instruction: Reports of the subgroups. National Institute of Child Health and Human Developent, National Institutes of Health

\section{AUTHOR'S BIOGRAPHY}

Joel Josumei Mbugua is postgraduate student in the department of Language and Literature Education, at Masinde Muliro University of Science and technology. He works as a teacher of English in Nandi South Sub-Couny Kenya.

Benard Angatia Mudogo works as a lecturer in the Department of Language and Literature Education at Masinde Muliro University of Science and Technology. He holds a PhD in Linguistics from Maseno University. He has extensively published nationally and internationally. His major research interests include; translation, cognitive linguistics, ecolinguistics and language teaching.

Teresa A. Okoth-Oluoch is a Lecturer at Masinde Muliro University of Science and Technology. She holds a PhD in Education from the University of South Africa (UNISA) and is also the director of career services at Masinde Muliro University.

Citation: Joel Josumei Mbugua, et al. Challenges of Correcting Spelling Errors among Standard Seven Learners in Nandi South Sub-County, Kenya. "International Journal on Studies in English Language and Literature (IJSELL), vol 8, no. 1, 2020, pp. 11-20. doi: http://dx.doi.org/10.20431/2347-3134.0801002.

Copyright: (C) 2020 Authors. This is an open-access article distributed under the terms of the Creative Commons Attribution License, which permits unrestricted use, distribution, and reproduction in any medium, provided the original author and source are credited. 